ACTA UNIVERSITATIS LODZIENSIS

FOLIA LITTERARIA POLONICA 8(38) 2016

http://dx.doi.org/10.18778/1505-9057.38.06

Barbara Stelmaszczyk ${ }^{*}$

\title{
Milosz: Self-Reflection as the Topic of a Poetic Description
}

Miłosz said that a biography starts where the awareness of one's fate begins; and fate stands for the participation in the earthly Movement of transience, which has its beginning and its end. Before that - before the awareness of one's individuality, of the very own "I" within the world is crystallised and manifested, thus before the biography - there is only the truth of a fairy tale. Human beings find out about their existence only when they lose it, that is at the moment when the conscious progress of the biography begins. Hence a biography is only a testimony of the truth that is lost.

Looking from the position of loss, as an owner of an individual biographical history, Miłosz, in one of his late story like poems ${ }^{1}$ - Do leszczyny (To a Hazel Tree) - tried to go down the "never-taken road" to reach the very beginning of this history, his own childhood, in order to extricate and describe ex post this elusive breakthrough, as well as this inevitable place, where the fable turns into the biography. To achieve his goal, the poet created a lyrical situation of encountering a hazel tree, a forest being elevated to the position of a persona, which remembers the character's childhood behaviour and him stalking "at the edge of a fairy tale". The poem has an apostrophic and a dialogical structure of a confession, which make it a manifest example of a fairy tale, where a lingual communication between a human and ontologically different beings is possible. Nevertheless, the dialogue which forms the lyrical situation in Miłosz's poem is incomplete, one-sided, based on one voice only - the voice of the lyrical subject who talks to the hazel tree:

Nie poznajesz mnie, ale to ja, ten sam,

Który wycinał na łuki twoje brunatne pręty,

Takie proste i śmigłe w biegnięciu do słońca.

$[\ldots]$

Szkoda, że tamtym chłopcem już nie jestem.

* Dr hab. prof. UŁ, University of Lodz, Faculty of Philology, Department of Romantic Literature, Institute of Polish Philology; e-mail: barbara@uni.lodz.pl.

${ }^{1}$ The poem was written in 1997 and a more precise location was postscripted by the author: “Szetejnie - Napa Valley, jesień 1997” (“Šeteniai - Napa Valley, autumn 1997”). 
$[\ldots]$

Kochałem twoją korę, brązową, z białym nalotem²

[You do not recognize me, but it's me all the same,

The one who used to make my bows by cutting your brown branches,

So straight and so swift in their reaching for the sun.

[...]

It's a pity I'm not a boy anymore.

$[\ldots]$

I loved your brown bark with its whitish tinge]

In its incompleteness, and in the breach of the fairy tale rule, this "lacking" dialogue still sheds light on the character's present cognitive viewpoint - a place of disinheritance, from which there is no going back to the beginning, to the state before the biography, to the unlimited possibilities of a fairy tale. It is only possible to shift back the one's "I" by means of inner memory lanes and the "Heraclitean meditation". However, one begins such a journey with a stigma of awareness, which distorts everything, thus making the road a "never-taken" one. The art of poetry, nonetheless, offers a chance to externalise the complicated duality of the speaking subject, as well as a chance to form a lasting impression of the lost truth of a fairy tale in the disenchanted space of "here and now":

Jest coś z heraklitejskiej zadumy, kiedy tutaj stoję,

Pamiętający siebie minionego ...

I próbuję w niej umieścić moje przeznaczenie ...

Byłem szczęśliwy z moim łukiem, skradając się brzegiem baśni.

Co stało się ze mną później, zasługuje na wzruszenie ramion I jest tylko biografią, to znaczy zmyśleniem.

[This is something of a Heraclitean meditation: I stand here

Remembering my bygone self

$[\ldots]$

And I try to locate my destiny in it

${ }^{2}$ All quotations of Czesław Miłosz's poems in Polish (except from the poems collected in Trzy zimy [Three Winters]) come from Wydawnictwo "Znak" editions: C. Miłosz, Wiersze wszystkie, Znak, Cracow 2011. The source of the poems is given in the main text, and the Arabic numeral points to the page number. Poems from the Trzy zimy (Three Winters) collection come from a separate source: C. Miłosz, Trzy zimy \& Głosy o wierszach, R. Gorczyńska, P. Kłoczowski (eds.), Aneks, London 1987. All quotations from the Trzy zimy (Three Winters) collection are marked with the TZ abbreviation, and depending on a poem, it is followed by the title and/or an Arabic numeral denoting the page number. 
$[\ldots]$

I was happy with my bow stalking at the edge of a fairy tale.

What happened to me later deserves no more than a shrug;

It is only biography, i.e., fiction.]

(Do leszczyny [To a Hazel Tree], 1141)

In the post scriptum, which unravels the culmination of the poem, the poet defined the biography as "fiction or a long dream". The individual quality of a biography - the human being, who is a subject, who walks through time and space, who constantly positions oneself in the centre - excludes the possibility of watching oneself from a distance. The taut string of experiences, dreams and perceptions, which constitute the individual "I" that is constantly on the existential move, looking around within external reality, variable, influenced by the suggestions of memory and their lack, inseparable from its perspective of nonfulfilment, incompleteness, but also split between the inner world and touching the external one - this "I" carries its history entangled in its own interpretation, more imagined and dreamt than real.

In Miłosz's autobiographical current there are, perhaps, two prominent and permanent threads. First, a thread of subjective sensations having the character of an epiphany, and second - somehow on the opposite end of the spectrum of such exalted experiences - a thread of awareness of one's "I", marked with an imperfection which is followed by fear, suffering and punishment for guilt that is unclear, unspecified (or indefinable). Both of them were often the subject of literary reflections ${ }^{3}$. This article, however, tries to elaborate on the aspect of a specific connection between these two aforementioned threads.

Jan Błoński, when analysing the motif of Eros in Miłosz's poetry, understood the concept along with the poet's suggestion presented in The Land of Ulro, where Miłosz mentioned his childhood fondness of a wooden squirrel toy, naming the affection "my Eros". He pointed also that the mentioned Eros:

was jealous and did not like me showing my affection to human beings, as he wanted to educate me to become an absolute servitor, who would be in love in each and every subject that exists - individually and collectively ${ }^{4}$.

According to this definition the specific desire that was experienced by Miłosz could also be expressed towards a picture, a bird, or even "the words of

${ }^{3}$ It was the second thread that gained much attention after Miłosz had published one of his latest collections To (This) in 2000, where the opening poem has the same enigmatic title. Both the title of the poem, and the attempts to depict and explain its meaning have become a subject of a broad exploratory afterthought.

${ }^{4}$ C. Miłosz, Ziemia Ulro, Znak, Cracow 1994, p. 46. 
one line claimed by a rhyme"s. Eros created by Miłosz worked not only within the erotic sphere of a fascination between people but it was also a craving for all/ different things in the world. For decades the poet had ardently claimed this world of great multiplicity of things, only to reach and depict their absolute and simultaneous fullness:

To znaczy zbierał co trzeba na jakiś ostatni moment

Kiedy z okruchów ułoży świat już doskonały.

[Which means he knew what was needed for some ultimate moment When he would compose from fragments a world perfect at last.]

(Pamiętnik naturalisty [Diary of a Naturalist], 637)

Miłosz's extraordinary Eros had thus a bearing on the author's vocation, he embodied a desire to encompass the multitude of all the things in the world by means of a word that is constantly elusive, sought and untraced, as the words are to contain the absolute unity of this multitude. There is one thought, one desire which reappears most often in this self-referential thread of Miłosz's poetry: to be the "absolute servitor" of poetry. Błoński justly pointed out that "the amorous experience in Miłosz's poetry... does not melt the individual in an anonymous pleasure. On the contrary, it exposes the possessive ego, which is so often mentioned in the poems". The scholar's conclusion is thus that, for Miłosz, "the ego, Eros, materiality and poetry stand on the same side" and that this is the source of drama, the source of the poet's Manichaeism. The truth of this theses, however, is based on the notion that one accepts the definition of Eros proposed by the poet as inalterably binding. Indeed, it works well when it comes to the exegesis of poems, examples of which are numerously presented in Jan Błoński's study: Epifanie Mitosza (Mitosz's epiphanies). Records of realizations found in this group of poems, sudden revelations of the lyrical "I" are described by the scholar as "poetical epiphanies", and this definition not only points to the place of these presentations and recognitions, the poetry as locum of the description, but also points to the revelational function of the poetic word which tries to name, thus to unravel the truth and fullness of reality. The theme, around which the author's experiences revolve, is based on capturing the existential truth at the moment of epiphany:

staną w blasku jakiejś jednej chwili wiosna i niebo, i morza, i ziemie.

\footnotetext{
${ }^{5}$ Ibidem.

${ }^{6}$ J. Błoński, Epifanie Miłosza, as cited in: idem, Miłosz jak świat, Znak, Cracow 1998, p. 63.
} 
[and in the splendor of one moment

stand spring and the sky, the seas, the lands.]

(Powolna rzeka [Slow River], 88)

- in which he feels that he attains "ruchomej granicy / Za którą spełnia się barwa i dźwięk / I połączone są rzeczy tej ziemi" ("the moving frontier / Beyond which colour and sound come true / And the things of this earth are united") (Mittelbergheim 351).

For a poet to capture the truth means also to express it with words. Błoński commented on the connection that:

There are so many moments, so many quotations! One could cite so many more. The poet speaks about something rudimentary for him. Something rudimentary for him being a poet. The moments of realizations, these epiphanies condition the very creation of a poem, they force to "seek words"... These moments are thus the incentive for work, as well as its aim? ${ }^{7}$.

Miłosz’s personal definition of Eros - somehow individual, legible and functional in relation to the group of poems analysed by Błoński (truly important and fundamentally crucial for Miłosz as an author) - differs, nonetheless, from the definition of the term in its basic, lexicographic, and common understanding, as an experience of sensual and physical love between people. The dissimilarity between the poet's Eros and the erotic sensations of ordinary commonalty (sometimes described this way by the poet himself), translates in his poetry into a peculiar opposition between the authorial lyrical subject (or rather subjects) and the human community. A sketch of such an unlikeness, separateness of one's "I" from the human community appeared in Miłosz' youthful, pre-WWII collection Trzy zimy (Three Winters), which was published in 1936. The collection serveed as a vital starting point for the autobiographical current in Miłosz's work, both because of the "psychic and magical incantation" that permeates the volume, and which was analysed by Renata Gorczyńska and Piotr Kłoczowski ${ }^{8}$, but also because of the manifested philosophical reflection, which strongly underpins the autobiographical thread, as well as influences its character. The importance of Trzy zimy (Three Winters) is even more crucial, for during the following decades, Miłosz did not deny those early poetical attempts to describe the originating individual fate, but developed and continued to contemplate the issues from the pre-war collection. It was in Trzy zimy (Three winters), at the beginning of the poet's artistic path, where his "I" was presented with quintessential choices, and it was also where his reflection was visibly demonstrated. This reflection, which permeated all his further works, concerns the

\footnotetext{
${ }^{7}$ Ibidem, p. 53.

${ }^{8}$ R. Gorczyńska, P. Kłoczowski, Nota redakcyjna, in: C. Miłosz, Trzy zimy..., p. VII.
} 
aforementioned split in the author's internal portrait, a split between two extreme sensations: on the one hand, there is a joyful, hymnic adoration of existence, and there is sorrow, misery, guilt and a feeling of being blemished on the other.

The dividing line which was sketched in Trzy zimy (Three Winters) - distinguishing the lyrical subject from the social community of people, from which they have their origins but from which they now detach - takes a tragic course. The disconnection is manifested in Miłosz's oppositions between "I" (and the equivalents of the authorial persona which take different pronouns: "you" or "he") and "they". The dialogical character of the poems published in this collection developed in two directions. Along with the opposition "I" - "they", there is the parallel authorial "I" which splits into different grammatical persons or other masking names ${ }^{9}$, which enter into a dialogue with themselves, which is, as a matter of fact, an internal dialogue of the textual representative of the author. The other direction is related to a specific mediatised soliloquy, in which "I" talks to itself represented by the second or third grammatical person ("you", "he"). One of these grammatically different personae can also talk about the others, thus it becomes a narrator of the story about its own different personifications. This multitude of voices, however, does not imply polyphony, and it is pointed out by Miłosz himself in his comments. The poet, when using many masks, presented himself in all of them but with a plural voice, a multiplied echo of many voices. This is how he created a distance from himself, and this "shifted" image, the portrait of himself detached from the pure lyricism, is given the reader to be considered.

Both lines of the above mentioned discourse, which is based on the dialogue principle, converge or cross, creating a complicated netting of dialogical spaces, which serve mainly to expose the anthropological afterthought, with a focus on self-reflection. Aleksander Fiut persuasively described this dialogue of authorial voices as a "game of identities" and a "negative faithfulness to oneself"

The "I" - "they" opposition is expressed in the opening poem Ptaki (Birds), where it provokes questions from the authorial porte parole about the identity, and where it exposes the split from the community of people described as "they".

Czem ja jestem, czem ja jestem i czem oni są?

Upici kwaśnym winem, czerwone wypieki

zakrywają i rzędem nad brzegami śpią.

\footnotetext{
${ }^{9}$ Here are some examples of the authorial "I" taken from the poems found in Trzy zimy (Three Winters): "uczeń marzenia" ("a dream's disciple") (p. 5); "niedobre dziecko" ("evil child") (p. 6); "ostatni z nosicieli kary" ("the last of the bearers of the verdict") (p. 7); "snu zdobywca" ("sleep conquerer") (p. 7); "Anna" (sic! - p. 9); "Ja, wierny syn czarnoziemu" ("I, a faithful son of the black earth") (p. 15); "uczeń" (“disciple") (p. 32); "podróżny świata" ("traveller of the world") (p. 36).

${ }^{10}$ See A. Fiut, Moment wieczny. O poezji Czesława Miłosza, Wydawnictwo Literackie, Warsaw 1993. Especially the chapter entitled: Gra o tożsamość.
} 
[What am I, what am I and what are they?

Drunk on bitter wine, they cover up their flushed

Faces and sleep in a row on the riverbanks.]

(TZ, Ptaki [Birds], 5)

The "I" is located on the same side with the "dream's disciple", and on the opposite side a dormant community of people becomes a multiplied bird traveller who builds up strength:

i podróżnicy, którym nadałem twarz ludzi,

To są ptaki, co we mnie gniazdo swoje wiły.

[And the travellers, whom I had given human faces,

Are the birds, who have woven their nests within me.]

$(\mathrm{TZ}, 5)$

The poem is a dialogical tale of the lyrical subject's identity split from the somnolent commonalty, which is passively immerged in the earthly rhythm of the "benign half-people's" existence. Landscape descriptions connote the author's childhood in Lithuania, as well as signal the autobiographical take on the issue. The subject's rebellious disagreement to a life obedient to the earthly ritual cycle is also manifested here, and their renouncement of the earth has a symbolic meaning. It is related to the inner space of the subject's thinking, where a resolution (or an inner compulsion) is made to break from a life which is obedient to the biological rhythm of nature, to denounce the agreement with the order of existence which advances death. The subject manifests their defiance of the rules by which "they" live - the dormant people, "powiązani skrzydłami w kolisko" ("in a ring of tangled wings").

Along with the subject's liberation from the earthly laws and desires, their importance is lost as well ("pragnienie, sen i miłość odtąd nic nie waży" ["Desire, dream and love won't carry weight from now on"] TZ, 5). The lightness and freedom that are gained in return ("lekkie ręce, $\mathrm{z}$ chmur lekkich altana i schron, / lekkie białe kamienie górzystych cmentarzy, / i wiatr, swobodny wiatr z dalekich stron" ["Light hands, arbour and shelter from light clouds, / Light white stones in the graveyards on the mountainside, / And wind, a free wind from far away"] TZ, 5) place the subject in opposition to the heavy besetment associated with the beauty of the now abandoned earth ("Dalej, dalej! Już ciebie żadna nie powstrzyma / piękność, ani zasłona ścieżek nie powlecze" ["Go on, go on! No beauty shall stop / You, no veil of paths shall coat you]; „sidło szczęścia już ciebie nigdy nie oplącze” ["the snares of happiness shall never entangle you again"] TZ, 7). 
The sound of a trumpet, also symbolic, calls to bid farewell and depart in order to reach a different, more conscious existence than the one of the dormant people with tangled wings. The subject looks for "live water", a deep consciousness, and with a heart stricken with this hunger, they leave, listening for the calling voice. It results in transferring into the sphere of individuality, into loneliness. It turns into an experience of a fracture, which, because of breaking the ties with the earth, becomes a stigma and a punishment for its creator. The secret calling voice means a desire to belong to these creators (like Dante) "którym wolno schodzić na dno gorejące" ("who descend to the fiery den") (to reach the core of recognition). The same secret calling voice (or cry) entangles the lyrical subject (and the authorial porte parole) in tragic (and exposed by a choir ${ }^{11}$ ) knowledge that the cry is a departure from the communal life with people, from whom the subject descends, banishing them for a symbolic journey to "the fiery den" through solitude. The subject has to adopt an attitude of a peculiar indifference to the abandoned earth. The call forces detachment ("Patrz, nawet z twojej ręki zranionej o głogi / chłód wypływa" ["Look, even your hand wounded by hawthorns / Oozes coldness"]), only to allow the subject to depart from the unity with "them", and not to entangle in the snares of earthly happiness, which only makes the flight more difficult. The poem thus becomes a "pieśn rozstania" ("a song of farewell"), according to which the subject, being the alter ego of the poet, departs, "ślady nóg w popękanym zostawiając żwirze" ("leaving footsteps in the cracked gravel") and makes it impossible to return ("mówiłem: powrócę, choć powrotu nie ma" ["I said: I will return, though there is no coming back"]). The song becomes a cry of horror, which "śpiące ziemie budzi" ("rouses sleeping lands"). The poetic images, which accompany the separation with the earth, are full of an apocalyptic and elegiac tonality:

Kto mnie wypomina

Te moje trudne próby, płomieni warownie

W sinej puszczy, samotność, zamknięte gorycze?

[Who reproaches me for

These tough trials, fortresses of fire

In the livid wilderness, loneliness, closed bile?]

(TZ, 6)

The one who leaves has a sense of great power and lightness, however, these feelings are restrained by terror depicted by a contrastive comparison of "moich przypływów" ("my tides"] and a vision of a cold late-autumn earth, where the

${ }^{11}$ The choir in the poem, which "zewsząd zrywa się i biegnie" ("starts and runs from everywhere"), is a dialogical opposition of truth to the subject's choices. 
bird travellers cry, as if they were calling for a departure in this frozen nightly landscape:

Żegnajcie! Śnieg upada na moje przypływy

Gwar tysięcy napełnia zamarzłe solawy,

Pelikany, żurawie z krzykiem w nocy brodzą

Niebo moje rozdarły czajek puste skwiry,

Listopadowe liście rany nie nagrodzą.

[Farewell! Snow falls on my tides

The babel of thousands fills the frozen waters,

Pelicans, cranes wade at night with a cry

My sky has been torn by pewits' empty squawks,

November leaves will not gratify my wound.]

$(\mathrm{TZ}, 6)$

The counter-voice which contests the subject's decision is manifested by means of the choir, which calls the subject "niedobre dziecko" ("evil child"), and tries to stop them:

Dziecko, niedobre dziecko, czemu nas budziłeś,

My byśmy, powiązani skrzydłami w kolisko,

Drzemali, aż do chwili, kiedy On rozdzieli

Ciebie i nas, ubogi czas i wielkie wszystko.

Dziecko, niedobre dziecko...

[Child, evil child, why did you wake us,

We would in a ring of tangled wings

Sleep till the time He parts you and us, the indigent time and the great things.

Child, evil child...]

$(\mathrm{TZ}, 6)$

It is too late, however, to withdraw while the love and warm affection towards the laws of earth have been rejected, the unity with nature has been broken, and the rights of Eros, who is inwrought in the earthly rhythm of passing, have been incinerated:

Wielkich spazmów miłości zakryta pieczara,

A jeśli słońce wschodząc jej bramy uchyli,

Syczą spalone zamki króla Baltazara, 
Oddane we władanie zimnym krzykom pawi.

Mży śnieg. I drzewo każde, przełamane, krwawi

[The covered cavern of the great spasms of love, And when the rising sun cracks open its gates

King Balthasar's burnt castles hiss,

Yielded over to the peacocks' cold screams.

Snow drizzles. And every tree, broken, bleeds]

$(\mathrm{TZ}, 8)$

The indicated fracture is irreversible, and the opposing images of the sun and coldness, love and broken bleeding trees emphasise the dramatic nature of the choice leading to the individual fate, from which there is no going back, because the inner voice of the subject's "I" is an aspiration of a higher consciousness than the one of "those" who "sleep in a row on the riverbanks".

This fate is not a complimentary gift. One has to pay for it with an irrevocable loss of the rejected values. One of them is Eros - an earthly love connected with pleasure, a source of an afterthought for Miłosz not only here, but also in his later collections - described as a love that is associated with nature and its motion towards death. There were many moments when the poet returned to the motif of Eros. In Ogród Ziemskich Rozkoszy (The Garden of Earthly Delights) Miłosz named the beauty of earthly things as "niezrozumiałe" ("incomprehensible") and pointed out to their "ponęta" ("lure"), which "mrowi się, spotyka / ... Na pospólne w nagości godowanie, / Na roziskrzenie oczu, słodki taniec / W żywiole powietrza, lądu i pieczar podziemnych, / Żeby przez krótką chwilę nie było śmierci / I czas nie rozwijał się jak nitka z kłębka rzuconego w przepaść" ("swarm, come together / ... For an endless wedding, / For the kindling of the eyes, for a sweet dance / In the elements of the air, sea, earth, and subterranean caves, / So that for a short moment there is no death / And time does not unreel like a skein of yarn / Thrown into an abyss") (784 - underlined by B.S.). The same afterthought can be found in the poem entitled Nad strumieniem (On the Banks of the Stream): "Albo nieme skały, jak w pierwszym dniu stworzenia, / albo życie, którego warunkiem śmierć, / i to upajające ciebie piękno" ("Either speechless rocks, like on the first day of creation, / Or life conditioned by death, / and this beauty which intoxicates you") (1153).

An especially pregnant poem, which has a character of a purposefully simplified axiological interpretation, is Antegor from Wiersze ostatnie (Last Poems). In the poem, death is identified with the devil, with "Książę Tego Świata" ("the Prince of This World"). The subject, or the poet himself wearing Antegor's mask, states: 
Władza Księcia Tego Świata jest dalej potężna

I skłania się ku niej każdy, kto chce żyć jak inni:

Jeść, pić, pracować, płodzić dzieci.

Jednym słowem zgadza się, żeby to co jest, dalej trwało

[...]

Antegor uważał, że akt seksualny oznacza przyjęcie warunku: chcesz żyć, no to umrzesz".

$[\ldots]$

był pewny, że nie przytrafi mu się nic złego,

Jeżeli nie opowie się po stronie życia,

Którego akt seksualny jest symbolem.

[The dominion of the Prince of This World is still powerful

And everyone, who wants to live like others, bows before it:

To eat, drink, work, to beget children.

In a word to agree that what exists shall continue

$[\ldots]$

Antegor considered the sexual act acceptance

of the terms: "You want to live, and so you'll die."

$[\ldots]$

he was certain that no harm would befall him,

As long as he did not side with life,

Of which the sexual act is a symbol.]

(1346-1347)

The lust for earthly pleasure thus involves the human in a pact of acceptance that death exists. The lack of reconciliation to "the Prince of This World" as the master of death forces the necessary decision to declaim against the earthly rituals of life. As a consequence, the rejection of earthly pleasure is to be a sign of defiance against death. Eros belongs to life thus anyone who does not accept the rules of the motion towards death and does not accept the condition Antegor speaks of, deprives themselves of the exalted joy of the sensation of love.

This conflict between the laws of the earth, in which the motion towards death can also be found, and the seeking for another space of fulfilment creates difficult choices, painful hesitation and renouncement of the authorial "I". Miłosz talked about it early in Trzy zimy (Three Winters) - a collection which can be compared to a musical motif expanded in different tonalities. This theme will later on extend and reappear in later poems, creating a great river of an autobiographical current permeating all Miłosz's work through decades. It is crucial that the beginning of the theme and the sketch of poetics, where the counterpoints of viewpoints 
and emotions create an inconclusive dialogue, are presented so early on, already in the $1930 \mathrm{~s}^{12}$.

In another poem from Trzy zimy (Three Winters) entitled Dialog (Dialogue), instead of a choir, there is a Guide who enters into a polemic discourse with a Learner, a child, "lekkomyślnym, chciwym wielbicielem krwi i księżyca" ("a thoughtless, greedy worshipper of blood and the moon"). The Guide cautions the Learner and tries to prevent him from leaving into the "ciemna, mglista strona" ("dark, misty side"), into the land of sorrow, "gdzie namiętności / żadnej już potok nie rozbrzmiewa głośny, / gdzie tylko z niebios zimnego ogrodu / spływa, silniejsze od promieni wschodu, / okrutne światło" ("Where there is no sound / Of the loud brook of passion / Where only from the cold heavenly garden / There flows, stronger than the rays of the east, / The cruel light"), and where "umyst, gorzkim poddawany próbom / błądzi, straciwszy milość swą na wieki” ("The mind, put to the bitter tests / Strays having lost its love for ever") (TZ, 33). I underline the mentioned notions: "namiętność" ("passion") and "miłość" ("love") as the earthly values which are at stake in the game between the Guide and the Learner. The Guide's gloomy characteristics of the land of a higher consciousness (and of art as well) to which the Learner is going, the one with its strong but cruel light, serves to expose the sceptical opposition presented by the Guide, whoever he is ${ }^{13}$,

${ }^{12}$ Their beginnings, traces or announcements can be found even in the poems preceding Trzy zimy (Three Winters). In Opowieść (A Story) Miłosz expressed a concept that the loves declared for women, as well as other earthly sensational experiences, belong to the rhythm of passing, whereas the counter force for this persistent earthly rule is to pursue another epiphany which encompasses the simultaneity of the multitude of events and which eludes time, one which "by w jednym mistycznym olśnieniu poznać serie obrazów, [...] patrzeć na rzeczy z ich zewnętrznej strony" ("to learn a series of images in one mystical epiphany, [...] to look at things from their outer side") (7). In Ludzie na ziemi (People on Earth) the human existence is presented as a biological process of passing, in order to finally "umarłym ciałem wykarmić maliny" ("feed raspberries with a dead body")(49), while the dead are replaced by other people, statistically anonymous, and although they are "silni" ("strong"), they are also "grobowi" ("deathful"). Similarly in a poetical letter entitled List 1/11935 R. (Letter 1/11935 R.), the lyrical subject poses a question full of horror, similar to the questions asked later in Trzy zimy (Three Winters), a question about the sense of life of people who are stuck in the sad motion towards death: "czymże oni są, czymże są, / już opadają w dół z krzykiem nieświadomości, / jak robactwo przepowiedziane przez Michała Anioła - / w ich oczach szklane światło, w ich rękach osłabłe bronie, / ich głowy w dół odwrócone na dno wiekuistość woła" ("What are they, what, / They are already falling down with the scream of unawareness, / Like the vermin prophesied by Michelangelo - / In their eyes vitreous light, in their hands weak weapons, / Their turned down heads are called by the eternity to the bottom") (52). In Zakończenie (The End) (23) one can find a sketch of a reappearing later in Miłosz's poetry opposition: a horror of life within the motion towards death - and a new, unknown love for "ludzkie dzieła" ("human creations"), when one can capture simultaneously the multitude of images and things, the plentitude of events.

${ }^{13}$ According to Aleksander Fiut: "The Guide in many respects resembles the priest Chomski from Rodzinna Europa (Native Realm)" (see the interpretation of the poem Dialog, in: C. Miłosz, Trzy zimy..., p. 114). The similarity to the priest Chomski is undeniable. In his interpretation, the scholar 
even a mask of the author himself, his other "I", which confronts the voice of the Learner with his inner conflict. On the one hand, the Guide presents the earthly passions and loves, on the other, however, he shows "umysł gorzkim poddawany próbom" ("The mind, put to the bitter tests") and wandering, as well as sorrow, as an inevitable consequence of loss of earthly enjoyments. The Learner, however, only listens to "suchego w skroniach szelestu" ("dry rustle in the temples"), to the rush of his blood, to his own "ognia pragnień" ("fire of the desire"), while he himself is "światłem i ruchem" ("the light and the motion"), who bonds the rhythm of his heart with the music of the poem, with the Muse, the art:

Dopóki ogień pragnień surowy

na usta spada,

w nieznanych nocy senne parowy

wiedzie mnie rada

Muza, muzyka. A sztuka wiersza

wiernie mi służy

i lekko biegnie za stukiem serca

jak deszcz po burzy

[Until the rough fire of the desire

Falls on the lips,

Into the unknown by night dreamy gullies

I am driven by the content

Muse, music. And the art of a poem

Serves me faithfully

And lightly follows the tapping of the heart

Like the rain follows the storm]

(TZ, Dialog [Dialogue], 31)

Similarly as in the poem Ptaki (Birds) lightness and liberty come from the subject, from within, from the rush of blood, which is harmonious with the art of the poem. The subject listens to their inner call, which is their longing, thus they cannot and do not want to listen to the Guide's warning not to break the ties with the earth. The Guide informs the Learner that the moment they leave "co było przez lata złączone / rozpadnie się" ("what was for years conjoined / will crumble"), and it will result in punishment. The Guide says:

focused on the opposition between the Guide and the Learner, nevertheless, he pointed out a tendency to an internal monologue, which seems to be a just indication of a vital function of the dialogue. 
Tam, w świata głuchych, wystygłych pałacach,

Donikąd wrócić nie będziesz się starał,

Wiedząc, że słuszna nastąpiła kara

Za młodość bujną, sztukę wiarołomną

[There, in the deaf, cold palaces of the world

You will not try to return anywhere,

Knowing that you were justly punished

For the vivid youth and the faithless art]

(TZ, 34)

The troubling thought that to serve the art involves this irreversible abnegation results in an intrusion of multiple voices of viewpoints and questions. In the poem Hymn (Hymn) the "I" is a subject who wishes to gain power just like the character of Konrad created by Adam Mickiewicz, who stands alone in front of God, empowered with the force that tears the world apart ${ }^{14}$. They are driven by a craving for recognition and "głos niewiadomy, bezosobowy" ("an unknown, impersonal voice"), which tells them to speak proudly to God: "Nikogo nie ma pomiędzy tobą i mną" ("There is no one between you and me").

The poem entitled Pieśn (The Song) emphasises the sensation of fear experienced by Anna, the lyrical subject, but, perhaps, the female name of the first person "I" is to soften the feelings and to intensify the nostalgia". Anna, similarly to the lyrical subject of Ptaki (Birds), rejects the connections with the earth, even though she is alarmed and fears loneliness: "Ziemia odpływa od brzegu, na którym stoję... Pączki kasztanów, światła lekkiej brzozy / już nie zobaczę was. / Z ludźmi umęczonymi oddalacie się, [...] boję się zostać sama... aż straszno mi patrzeć na siebie, Ziemio, / nie opuszczaj mnie" ("Earth flows away from the shore where I stand... Buds of chestnuts, lights of frail birches, / I won't see you anymore. / With worn-out people you move away, [...] I am afraid to stay here alone... I am scared to look at myself. Earth, / do not abandon me.”). The resignation from the tempting beauty of the earth, however, returns in an ambivalent way: "Nie chcę ciebie, nie skusisz mnie. [...] Noce miłosne z tobą gorzkie jak popiół chmur... Ty, Boże, miłościw mnie bądź. Od ust ziemi chciwych odłącz mnie. / Od pieśni jej nieprawdziwych oczyść mnie” (“I don’t want you, don’t

${ }^{14}$ The similarity between the "I" created by Miłosz and Konrad from the third part of Dziady (Forefathers' Eve) written by Mickiewicz was pointed out by Marek Zaleski, who analysed Hymn (Hymn) along with Miłosz's comments. See: C. Miłosz, Trzy zimy..., p. 75.

${ }^{15}$ The poet changed the name "Anna" to "Woman" in later editions. I am writing, however, about the first version of the poem, as, in the context of this article, Miłosz's play with the masks is of paramount importance, and the name "Anna" serves as a far more hidden "I", than the latter, less marked, and less meaningful anonymous "Woman". 
tempt me, [...] Nights of love with you bitter as the ash of clouds... You, God, have mercy on me. / from the earth's greedy mouth deliver me, / cleanse me of her untrue songs") (underlined by B.S.). The subject is also engulfed in the element of rush and turned into the wind, again, similarly like in the poem Ptaki (Birds):

Ja jestem wiatr, co niknąc w ciemnych wodach dmie,

Wiatrem jestem idącym a niewracającym się,

Pyłkiem dmuchawca na czarnych łąkach świata.

[I am the wind that blows and dies out in dark waters,

I am the wind going and not returning,

a milkweed pollen on the black meadows of the world.]

(TZ, Pieśń [The Song], 11)

The voice of the choir again serves as a counterpoint to Anna's ambivalent sensations (this is also similar to the construction found in Ptaki [Birds]). The voice is a collective voice of a community, and praises the beauty and joy of life on the earth:

Radość wszelka jest z ziemi, nie masz prócz ziemi wesela,

Człowiek jest dany ziemi, niech ziemi tylko pożąda.

[All joy comes from the earth, there is no delight without her, man is given to the earth, let him desire no other.]

$(\mathrm{TZ}, 9)$

These voices, however, of the Guide and of the choir, as well as the beautiful, sensual descriptions of nature, which testify to the earth's fairness, mainly, are supposed to serve as a counterbalance in the disputation. They meet the classic rules of rhetoric, only to strengthen their argument, the voice and the subject's contra.

In the poems Posag matżonków (Statue of a Couple), and especially in Bramy arsenatu (The Gates of the Arsenal), the sensation of Eros as an amorous connection of the lovers is described as even more drastic than Anna's bitter confession - its imagery is full of pejorative meanings, and the tonality is dark and disturbingly bitter. In Bramy arsenatu (The Gates of the Arsenal) Eros is described as "brodacz stróż kłusuje na krzywym koniku, / na złotej strzale niosąc cięciwę napiętą" "“a bearded keeper [who] trots on his crooked horse, / Carrying a golden arrow in the taut string of his bow") and who accompanies the young woman, who "dąży, nie znając głębi zamglonych ogrodów" ("goes unaware of the depths 
of the misty gardens"), "stopą w fałszywej stąpającą ciszy" ("pacing in false silence"). The description of the amorous act that follows the introduction is closed by a surprising comment, which entering the catastrophic contexts, summarises the erotic experience in a disastrous way:

Srebro sączy się w usta, lęk rumieńce ściera, pierś stężała w dwa sople niespokojnie dyszy, blask tnie. Od światła wszystko co żywe umiera.

Suknie spadną zetlałe, krzak włosów zgoreje i brzuch goły odsłoni jak koło z mosiądzu, uda ruchliwe odtąd marzeniem nie rządzą, nagie i czyste dymią jak rude Pompeje.

A jeśli dziecko zrodzi się z tej krwi słowiańskiej, patrząc bielmem, łbem ciężkim na stopnie potoczy i z czworgiem łap w powietrzu w dzień będzie i w nocy spać, jak koń martwy w runi wypalonych pastwisk.

[Silver seeps into her lips, fear bleaches her face, The breasts, two icicles now, restlessly heaves, The glare strikes. And touched by light, all that lives dies.

Her dress will fall off in flames, the bush of hair will blaze And reveal her belly like a copper disk.

Her nimble thighs no more rule over dreams,

Naked and pure they smoke like auburn Pompeii.

And if a child is born of that Slavic blood, White-eyed, it will strike its head hard against the steps And sleep with its four legs up, day and night, As a dead horse sleeps amid burned-out pastures.]

(TZ, Bramy arsenatu [The Gates of the Arsenal], 65)

The "false silence" of the unknown, misty gardens becomes thus a meaningful suggestion to the location of the amorous experience, and future effects of Eros's actions are presented by means of a hypothetic mood, as a gloomy vision in which the Slavic child, born from this love, belongs to the animalistic nature, which is scorched, dead and terrifying.

Jan Błoński, when analysing Miłosz’s poetry, stated that this power, and the desires connected with it could be placed within the art, which reaches beyond 
the rule of the earthly existence. The dream of such love's fulfilment is visible in all Miłosz's poems. In the end of the 1960s, in the Miasto bez imienia (City Without a Name) collection, the poet wrote about going "Do niedosiężnej kotliny ocienionej na zawsze słowami, gdzie nagich klęczących obmywa źródło nierzeczywiste" ("To the unattainable, small valley, shaded forever by words, where the / two of us, naked and kneeling, are cleansed by an unreal spring") ( $W$ drodze [On the Road] 577). This vision is connected with his individual definition of Eros, which was already discussed in this article. It is a different love and a different longing, one that derives from the inner premonitory voice and tells the lyrical subject to choose hardship and joy of the author, which can be achieved in the "second space" - the space which is searched for by the earthly being, the human who is split into two of these locations:

Sława, szepcą klony, od każdej żywej istoty przebiega do twoich dłoni niewidzialna uzda - targniesz - i wszystko zakręca w półkole pod baldachimem nazywanym cirrus. A prace jakie są? O, ciebie czeka jodłowa góra, na niej tylko zarys wielkich budowli, dolina gdzie zboże wzrosnąć powinno, stół i biała karta, na której może poemat powstanie, radość i trud.

[The invisible rein on every living thing leads to your hand - pull, and they all turn a half-circle under the canopy called cirrus. And your task? A wooded mountain awaits you, the place for cities in the air, a valley where wheat should grow, a table, a white page on which, maybe, a long poem could be started, joy and toil.]

(TZ, Powolna rzeka [Slow River], 35-36)

In the early collection the "other" longing is but a promise, a premonition, an opening of the unknown, but ardently craved space, however, it is in Trzy zimy (Three Winters), where the gesture of leaving the earthly garden is burdened with the awareness of the subject's split. It is expressed by means of the imagery presenting oppositional sensations: heftiness and lightness, the overpowering pain of rejection of the earthly gifts and the wind, which carries effortlessly when "droga umyka spod nóg" ("the road bolts like an animal") 
$(\mathrm{TZ}, 36)$. The apple from the Edenic tree is heavy, but the foot which nudges it is weightless:

Dojrzałem, moje ciało jest czułą kołyską

dla mocy, w których płaczu zawiera się wszystko,

leżą w pięknem posłaniu i miłość i głód.

Wiatr swobodnych poranków we włosach powiewa i jabłko,

ciężkie jabłko, sen rajskiego drzewa toczy się, potrącane końcem lekkich stóp.

[I have matured, my body a tender cradle

For the powers, in the cry of which there is everything,

They lie in the beautiful pallet both love and hunger.

The wind of the casual mornings streams in hair,

And an apple, the heavy apple, the dream of the Edenic tree

Rolls nudged by the tiptoes of light feet.]

(TZ, Do księdza Ch. [To Father Ch.], 51)

$* * *$

Years later, in Piesek przydrożny (Road-side dog) published in 1997, Miłosz confirmed his early intuitions that the path which the poet must take requires an absolute commitment to the art. From the perspective of life experience and fame, as well as literary accomplishments, he added that service in the name of art "unfortunately means indulging into servitude of one's ego", which he then described as "childish egoism" and the "flaw of the incomplete humanity"16. This mature work, written as prose poetry, does not undermine the self-thematic afterthought found in Trzy zimy (Three Winters). On the contrary, it is rather strengthened. The text also continues the mask game, as the subject is represented by the third person singular pronoun "he". What is new and different from the early collection published in the 1930s, however, is the search for reconciliation between the two spheres. Then the poet noticed in the human community not the "spiący półludzie" ("dormant half-people"), he once accused rebelliously of passiveness, but "prawdziwie wielcy, siłą litości, współczucia i miłości, święci bohaterzy" ("truly great and holy heroes in their power of mercy, compassion and love"). The lack of such a power within himself was perceived by the poet as a flaw, while the power within those people became a source of admiration. Literature, however, the space in which the author performed, appeared to be a compensation, a redress for the flaw of the human incompleteness. It became a redemption for this guilt:

${ }^{16}$ C. Miłosz, Zamiast, in: idem, Piesek przydrożny, Znak, Cracow 1997, p. 20. 
Jeżeli urodziłem się takim, że daremnie bym próbował oczyszczenia i wyzwolenia - powiedział - niech przynajmniej moje dzieło okupi moją słabość i pomoże wielbić w ludziach wspaniałość serca ${ }^{17}$.

[If I was born to unavailingly try purgation and liberation - he said - at least let my child be the one to compensate for my weakness and help worship in people the glory of the heart.]

"Podziw" ("amazement") is a key word in Miłosz's poetry. It allowed him to coexist with people, to disperse fears. The moment it appears, it reconciles the poet with the nature of the world. It also opens the space of Miłosz's epiphanies. The poet was looking for the accomplishment of these epiphanies in this second space, within the spiritual land of "pozaziemskie łąki" ("the meadows of the beyond") and used to find it even when he bitterly recollected that people had lost this land, losing their faith in God. It was exactly then, when he re-established the epiphanic images by means of the poetic word:

Jakie przestronne niebiańskie pokoje!

Wstępowanie do nich po stopniach z powietrza.

Nad obłokami rajskie wiszące ogrody.

Dusza odrywa się od ciała i szybuje,

Pamięta, że jest wysokość

I jest niskość.

[How spacious the heavenly halls are!

Approach them on aerial steps.

Above white clouds, there are the hanging gardens of paradise.

A soul tears itself from the body and soars.

It remembers that there is an up.

And there is a down.]

(Druga przestrzeń [Second Space], 1217)

This "druga przestrzeń" ("second space”) of Miłosz - the artist - is created in art:

Pługi zaorzą las. Tylko flet i skrzypce

Będą pracować, jak im nakazałem.

${ }^{17}$ Ibidem. 
[The ploughs will erase a forest. The flute and the violin Will always work as I have ordered them.]

(Mistrz [The Master], 481)

Poetry, as it belongs to the "second space", defeats the earthly law of passing and moves in the direction of death, it spreads where "ustaje czas, daleko, daleko / Od ludzkiej nienawiści i ludzkiej miłości" ("the time stops, far, far away / From human hatred and human love ") (Do poezji [To Poetry], 132). It is truly the lady of Miłosz's heart, of Miłosz the creator, an object of desire, a starting point of his journey, where the poet found the hymnic adoration within himself:

Ty, która jesteś zarysem nozdrzy nie urodzonego jeszcze konia,

Kształtem i barwą jabłka, które rozpadło się w pył,

Błyskiem skrzydeł jaskółki, co dotknęła głowy Tyberiusza W określonym punkcie wieczności

[You, who are the sketch of nostrils of a yet unborn horse,

The shape and the colour of an apple which turned into dust,

The sparkle of the swallow's wings, which touched Tiberius's head

At the specific point of eternity]

(Do poezji [To Poetry], 132)

The art of poetry is a gift with a high price in the human dimension of fate, which is designated by the inner premonitory voice: It comes from the desire and is an affection which requires a full dedication. Nonetheless, it disables the human, and for that, consequently, the human has to be punished. But this art is a pristine gift, an expiation, a redemption:

Kochałem jednak moje przeznaczenie.

I gdybym cofnął czas, czy wybrałbym uczciwość, Nie potrafię odgadnąć. Linia losu nie wie.

Czy Bóg chce, żebyśmy gubili duszę,

Bo tak ma tylko dar nieskazitelny?

[And yet I loved my destiny.

Could I move back in time, I am unable to guess

Whether I would have chosen virtue. My line of fate does not tell.

Does God really want us to lose our soul

For only then He may receive a gift without blemish?]

(Mistrz [The Master], 482) 
Miłosz's elocution thus tried to reach the hymnic aspect, the song of laudation, which adores the beauty of the world and its incomprehensible multitude of things, fragrances and colours. It tried to describe the "nieobjęta ziemia" ("unattainable earth") in single events, sensations and details because: "Prawdziwy wróg człowieka jest uogólnienie" ("The true enemy of man is generalization") (Sześć wykladów wierszem, Wyklad IV, 968). The poet, by means of poetry, ardently tried to fight his individual human blemish, but also, in general, the flaws of human fate destined for death. He strived uneasy, not sure if he had enough time:

Tak mało powiedziałem.

Krótkie dni.

Krótkie dni,

Krótkie noce,

Krótkie lata.

[...]

Serce moje zmęczyło się Zachwytem,

Rozpaczą,

Gorliwością,

Nadzieją.

[I said so little.

Days were short.

Short days.

Short nights.

Short years.

[...]

My heart grew weary

From joy,

Despair,

Ardour,

Hope.]

(Tak mato [So Little], 627)

The poet was restless because the conflict between the desire of the hymnic epiphany and the experience of suffering and blemish, which cannot be described in any other way than "TO" ("THIS"), never dies. The ambivalence did not leave Miłosz, who then confessed that "ekstatyczne pochwały istnienia / Mogły być tylko ćwiczeniami wysokiego stylu, / A pod spodem było TO... Ponieważ TO oznacza natknięcie się na kamienny mur, / i zrozumienie, że ten mur nie ustąpi żadnym naszym błaganiom" ("my ecstatic praise of being / Might just have been exercises in the high style. / Underneath was this... This. Which signifies knocking 
against a stone wall and knowing that the wall will not yield to any imploration") (To [This], 1139-1140). On the other hand, however, he rose above the penitential suffering in his hymnic adoration of existence. This adoration consisted of the admiration, when the subject - looking from the outside - understands the whole, the fullness, and experiences the joy of being a part of it:

O, jaka zorza w oknach. I działa bija.

Nilem zielonym płynie koszykowa łódka Mojżesza.

Nieruchomo stojąc w powietrzu nad kwiatami lecimy.

Śliczne goździki, piękne tulipany na niskich stołach.

Słychać i rogi myśliwskie, ogłaszają Halla-li.

Nieprzebrane, niepoliczone substancje ziemi.

Zapach cząbru, kolor jodły, szron, tańce żurawi.

A wszystko równoczesne. I chyba wieczne.

Oko nie widziało, ucho nie słyszało, a to było.

Struny nie wygrają, język nie wypowie, a to będzie.

Lody malinowe, topniejemy w niebie.

[O what daybreak in the windows! Cannons salute.

The basket boat of Moses floats down the green Nile

Standing immobile in the air, we fly over flowers:

Lovely carnations and tulips placed on long low tables.

Heard too are hunting horns exclaiming hallali.

Innumerable and boundless substances of the Earth:

Scent of thyme, hue of fir, white frost, dances of cranes.

And everything simultaneous. And probably eternal.

Unseen, unheard, yet it was.

Unexpressed by strings or tongues, yet it will be.

Raspberry ice cream, we melt in the sky.]

(Podziw [Amazement], 699)

\section{Bibliography}

Błoński Jan, Epifanie Miłosza, in: idem, Miłosz jak świat, Wydawnictwo “Znak”, Cracow 1998.

Fiut Aleksander, Moment wieczny. O poezji Czesława Miłosza, Wydawnictwo Literackie, Warsaw 1993.

Miłosz Czesław, Trzy zimy \& Głosy o wierszach, R. Gorczyńska, P. Kłoczowski (eds.), Aneks, London 1987.

Miłosz Czesław, Wiersze wszystkie, Wydawnictwo “Znak”, Cracow 2011.

Miłosz Czesław, Zamiast, in: idem, Piesek przydrożny, Wydawnictwo "Znak”, Cracow 1997.

Miłosz Czesław, Ziemia Ulro, Wydawnictwo “Znak”, Cracow 1994. 


\section{Barbara Stelmaszczyk}

\section{Miłosz: Self-Reflection as the Topic of a Poetic Description}

\section{(Summary)}

Czesław Miłosz's poetry displays two reverberating topics which may be defined as contradictory existence and world experiences. One of those is the admiration for the beauty of the world and awe consequent upon capturing the simultaneous existence of individual entities (Amazement), whilst the other is the topic of the lack of fulfilment, torment, the feeling of lack of authenticity, blame, and shame (This).

Miłosz depicted his "I" (represented by various personae), the split between individual consciousness, a strong sense of individuality, distinct from the commune of ordinary people (a strand salient in the pre-war volume Three Winters), at the same time nurturing a feeling of strong bonds with the society.

The poet's self-reflection holds for both topics, while the autobiographic discourse is orientated to the questions about the functions of the poetic language and about the status and sense of poetry, thereby addressing the self-topicality.

Keywords: Czesław Miłosz, Three Winters, poetry 